\title{
David E. Rothstein \\ Spring ephemeral herbs and nitrogen cycling in a northern hardwood forest: an experimental test of the vernal dam hypothesis
}

Received: 24 August 1999 / Accepted: 23 March 2000

\begin{abstract}
In the late 1970s R.N. Muller and F.H. Bormann posited their "vernal dam" hypothesis, stating that spring-ephemeral herbs in deciduous forests serve as a temporary sink for $\mathrm{N}$ when overstory trees are dormant, and then release this $\mathrm{N}$ later, in the summer, when the trees are active. This hypothesis has gained wide acceptance, yet two of its critical assumptions have never been experimentally tested: (1) that $\mathrm{N}$ taken up by spring ephemerals would otherwise be lost from the ecosystem, and (2) that $\mathrm{N}$ from senesced ephemeral tissues contributes to increased rates of summertime $\mathrm{N}$ mineralization. To test these assumptions, I quantified patterns of $\mathrm{N}$ cycling and loss from a set of paired plots, half of which served as controls and from half of which all springephemeral plants were removed. There were no significant differences in $\mathrm{NO}_{3}{ }^{-}$leaching between plots with and without spring ephemeral vegetation. These results are consistent with the relatively low rates of $\mathrm{N}$ uptake by the dominant spring ephemeral, Allium tricoccum, and its apparent preference for $\mathrm{NH}_{4}^{+}$, which is far less mobile in soil than $\mathrm{NO}_{3}{ }^{-}$. In addition, based on sequential sampling, I found that soil microorganisms took up 8 times as much $\mathrm{N}$ during the spring than did springephemeral herbs (microbial uptake $=3.19$ vs. plant uptake $=0.41 \mathrm{~g} \mathrm{~N} \mathrm{~m}^{-2}$ ), suggesting that microbial immobilization of $\mathrm{N}$ is the dominant sink for $\mathrm{N}$ during this season. Removal of spring ephemeral vegetation also had no effect on summertime rates of net $\mathrm{N}$ mineralization. Furthermore, the addition of spring ephemeral litter to soil+forest floor microcosms did not significantly increase rates of $\mathrm{N}$ mineralization in a laboratory incubation. Instead, this experiment demonstrated the overwhelming influence of forest floor litter in controlling
\end{abstract}

D.E. Rothstein (

School of Natural Resources and Environment,

University of Michigan, Ann Arbor, MI 48109-1115, USA

Present address:

D.E. Rothstein, Department of Biological Sciences,

Stanford University, Stanford, CA 94305, USA,

e-mail: davidr1@stanford.edu,

Tel.: +1-808-9678255, Fax: +1-808-9678255 the release of mineral $\mathrm{N}$ from these soils. Overall, neither assumption of the vernal dam hypothesis holds true in this ecosystem, where patterns of $\mathrm{N}$ cycling and loss appear to be dominated by microbial decomposition of forest floor material and soil organic matter.

Key words Vernal dam $\cdot$ Spring ephemerals . $\mathrm{NO}_{3}{ }^{-}$leaching $\cdot$ Microbial biomass $\cdot \mathrm{N}$ immobilization

\section{Introduction}

In the late 1970s Muller and Bormann (1976) observed that nitrogen $(\mathrm{N})$ uptake by spring ephemeral vegetation in early spring was similar in magnitude to hydrologic losses of $\mathrm{N}$ from a northern hardwood ecosystem. This observation led them to posit the "vernal dam" hypothesis, that spring-ephemeral herbs increase ecosystem stability by serving as a temporary sink for nutrients when trees are dormant, and then releasing these nutrients later in the growing season when trees are active. Since that time, researchers duplicating their methods in other deciduous forests have found that spring ephemerals consistently take up amounts of $\mathrm{N}$ that are comparable to annual losses, and thus have concluded that these plants play an important role in ecosystem nutrient retention (Blank et al. 1980; Peterson and Rolfe 1982). Despite the fact that critical assumptions of the vernal dam hypothesis have not been experimentally tested, the importance of spring ephemeral herbs in limiting nutrient losses from deciduous forest ecosystems appears to be widely accepted to this day (Eickmeier and Schussler 1993; Farnsworth et al. 1995; Jandl et al. 1997; Tardiff and Stanford 1998).

The two critical assumptions of the vernal dam hypothesis which need to be tested are: (1) that nutrients taken up by spring ephemerals would otherwise be lost to leaching, and (2) that the decomposition of ephemeral litter increases summertime nutrient availability (Muller and Bormann 1976). There are several a priori reasons to question the validity of these assumptions as they pertain 
to ecosystem $\mathrm{N}$ cycling. For one, there has been a growing appreciation of the importance of soil microorganisms as a sink for N (Vitousek and Matson 1984; Jackson et al. 1989; Stark and Hart 1997), and even some evidence that, over the short term, soil microbes can outcompete spring ephemeral plants for ${ }^{15} \mathrm{~N}$-labeled $\mathrm{NH}_{4}{ }^{+}$ and $\mathrm{NO}_{3}{ }^{-}$(Zak et al. 1990; Groffman et al. 1993). Moreover, the fact that the amount of $\mathrm{N}$ returned in senesced spring ephemeral leaves is very small compared to the amount of $\mathrm{N}$ returned in overstory litter, and minuscule compared to soil organic matter pools, suggests that spring ephemerals are not likely to have much effect on rates of summertime $\mathrm{N}$ mineralization. For example, in Watershed 6 of the Hubbard Brook Experimental Forest, the $1-2 \mathrm{~kg} \mathrm{~N} \mathrm{ha}^{-1}$ year-1 $^{-1}$ released from spring ephemerals (Muller and Bormann 1976) is almost 2 orders of magnitude smaller than either the $54 \mathrm{~kg} \mathrm{~N}^{-1}$ year $^{-1}$ released in canopy litterfall, or the $70 \mathrm{~kg} \mathrm{~N} \mathrm{ha}^{-1}$ year-1 mineralized from soil organic matter (Bormann et al. 1977).

I set out to test these assumptions experimentally in a northern hardwood forest characterized by rapid rates of N cycling (Zak and Pregitzer 1990), and a well developed spring ephemeral community (Host and Pregitzer 1991). I removed spring-ephemeral vegetation from experimental plots and compared patterns of $\mathrm{N}$ cycling and loss between these plots and controls. I hypothesized that the $\mathrm{NO}_{3}{ }^{-}$concentration of soil water and $\mathrm{NO}_{3}{ }^{-}$leaching losses would be greater in plots from which spring ephemerals had been removed than in those containing an intact cover of spring ephemerals. Also, I hypothesized that summertime rates of net $\mathrm{N}$ mineralization would be greater in plots with spring ephemerals than in those without. In order to evaluate the potential for soil microorganisms to function as an alternative sink for $\mathrm{N}$ during the spring, I characterized seasonal changes in microbial biomass $\mathrm{N}$ in both control and removal plots.

\section{Methods}

Study site and experimental design

My study was conducted in a single stand of northern hardwood forest located in northern Lower Michigan, United States $\left(44^{\circ} 20^{\prime} \mathrm{N}, 86^{\circ} 00^{\prime} \mathrm{W}\right)$. This particular stand has been classified as belonging to the sugar maple-basswood/Osmorhiza ecosystem type by Host and Pregitzer (1991), an assemblage characterized both by an abundant and diverse spring ephemeral community and some of the most rapid rates of net $\mathrm{N}$ mineralization and nitrification in the region (Zak and Pregitzer 1990). Allium tricoccum Ait. is the dominant spring ephemeral species at this site, both in terms of percent cover and in terms of biomass. The other spring ephemerals growing at this site were Claytonia virginica L., Dicentra canadensis (Goldie) Walp., D. cucullaria (L.) Bernh., and Erythronium americanum Ker. (nomenclature for all species follows Gleason and Cronquist 1991).

In August of 1996, five pairs of $3 \times 3$ m plots were located systematically throughout the stand. Suitable locations for paired plots were selected on areas of level ground free from pits, mounds, or large downed trees. Within each pair, plots were randomly assigned to either control or spring-ephemeral removal treatments. Beginning at snowmelt in 1997, and continuing through canopy closure, all spring ephemeral plants were clipped
Table 1 Comparison of early spring, 1998 ephemeral stem density between control and removal plots. Values are means \pm 1 SE $(n=10$; (stems $\mathrm{m}^{-2}$ )

\begin{tabular}{llrl}
\hline Species & Control & Removal & $\begin{array}{l}\text { Reduction } \\
(\%)\end{array}$ \\
\hline Allium tricoccum & $26.4 \pm 7.8$ & $2.2 \pm 0.4$ & 92 \\
Claytonia virginica & $52.6 \pm 14.0$ & $12.4 \pm 4.5$ & 76 \\
Dicentra spp. & $37.4 \pm 16.5$ & $4.7 \pm 2.3$ & 87 \\
Erythronium americanum & $20.4 \pm 5.8$ & $3.2 \pm 0.9$ & 84 \\
\hline
\end{tabular}

at least twice weekly in the removal plots. Because A. tricoccum and E. americanum had deeply buried bulbs, their stems were clipped at the soil surface as they emerged. In contrast, most $\mathrm{Di}$ centra and $C$. virginica bulbs were between the surface of the mineral soil and the forest floor, and had very delicate root systems, so that entire bulbs could be removed with very little soil disturbance. This process was repeated in the spring of 1998. For the purposes of censusing the spring ephemeral vegetation, two $1-\mathrm{m}^{2}$ subplots were located in opposite corners of each plot. The effectiveness of the removal treatment was demonstrated by the 80-90\% reduction of spring ephemeral stem density in removal census plots relative to the control census plots (Table 1).

Also in August 1996, three ceramic cup lysimeters were located in the center of each plot and configured so that each cup was approximately $50-\mathrm{cm}$ deep and $1.0-1.5 \mathrm{~m}$ from the nearest plot edge. Adjacent lysimeter cups were approximately $50 \mathrm{~cm}$ apart. A depth of $50 \mathrm{~cm}$ was chosen so that the lysimeters would be deep enough to collect water below the majority of plant roots (Gale and Grigal 1987), yet shallow enough that lateral flow of water from outside the plot to the cups would be unlikely. To minimize disturbance effects during sample collection and clipping, I consistently entered each plot only in front of where the lysimeters emerged from the soil. This ensured that the area directly above the lysimeter cups was untrampled. Soil samples were collected from the margins of each plot at monthly intervals in 1997 (8 sampling dates), at three-week intervals from March through June 1998 (5 sampling dates), and 5-week intervals from July through November 1998 (4 sampling dates). Soil samples were taken from positions $c a .15 \mathrm{~cm}$ inside the plot edge, and $c a .30 \mathrm{~cm}$ in a clockwise direction from the position at the previous sampling date. Soil samples were taken from the periphery of the plot to avoid disturbing the area over the lysimeters. At each sampling date, two replicate soil samples were collected at opposite ends of the plot.

Uptake and release of $\mathrm{N}$ by the spring ephemeral community

In order to compare the results of my experimental methods to those in the literature, I replicated the sampling design of Muller and Bormann (1976) and Blank et al. (1980). On 15 May 1997 I censused the number of stems of each spring ephemeral species (D. cucullaria and D. canadensis were lumped together as Dicentra spp.) in the $1-\mathrm{m}^{2}$ subplots of each control plot $(n=10)$. On 9 April, 15 May, and 14 June 1997, I used a shovel to collected ten intact blocks of soil ( $c a .0 .1 \mathrm{~m}^{2} \times 0.1 \mathrm{~m}$ deep) at random locations throughout the stand (not in experimental plots). Spring ephemeral plants in these sods were sorted free of soil particles and leaf litter, counted, and oven dried to a constant weight at $70^{\circ} \mathrm{C}$. Once dry, all individuals of each species were composited by tissue (leaves, bulbs, roots), weighed, and ground to a fine powder using a mortar and pestle. Five replicate subsamples of each tissue were analyzed for $\mathrm{N}$ concentration using an NC 2500 Elemental Analyzer (CE Elantech, Lakewood, N.J., USA). These data were used to calculate the average $\mathrm{N}$ content per stem of each species, which was multiplied by the stem density in each subplot to determine the amount of $\mathrm{N}$ in spring ephemeral biomass on an areal basis $(\mathrm{g} \mathrm{N}$ $\mathrm{m}^{-2}$ ). Net $\mathrm{N}$ uptake by the spring ephemeral community was calculated as $\mathrm{N}$ content on 15 May minus $\mathrm{N}$ content on 9 April, and 
net release of $\mathrm{N}$ was calculated as the difference in $\mathrm{N}$ content between 15 May and 14 June.

\section{Effects of spring ephemeral vegetation on $\mathrm{N}$ leaching}

In both 1997 and 1998, tension (ca. $35 \mathrm{kPa}$ ) was applied to the lysimeters once snowmelt had reduced general snow depth to approximately $5 \mathrm{~cm}$. From this point on, water samples were collected at least once every 2 weeks throughout spring and at least monthly from summer through autumn; samples were collected more frequently during periods of heavy rainfall. Soil water concentrations of $\mathrm{NH}_{4}{ }^{+}$and $\mathrm{NO}_{3}{ }^{-}$were determined using an Alpkem Rapid Flow Analyzer (Astoria Pacific, Clackamas, Ore., USA). Ammonium concentrations, when detectable, were generally less than $0.1 \mu \mathrm{g} \mathrm{N}$ $\mathrm{ml}^{-1}$, and are not reported. At each sampling date, the $\mathrm{NO}_{3}$ concentrations from the three lysimeters within each plot were averaged to generate plot means, which were used for all statistical analyses. A monthly water balance (Thornwaite and Mather 1957) was used to convert $\mathrm{NO}_{3}{ }^{-}$concentrations at $50 \mathrm{~cm}$ depth to areal leaching losses $\left(\mathrm{g} \mathrm{N} \mathrm{m}^{-2}\right.$ month $\left.^{-1}\right)$. This method calculates hydrologic losses as the amount of precipitation in excess of estimated actual evapotranspiration and soil water holding capacity. I assumed that differences in evapotranspiration between control and removal plots due to the elimination of spring ephemeral leaf area were insignificant.

In order to investigate the potential for soil microorganisms to function as an alternative sink for $\mathrm{N}$ during the spring, I measured changes in soil microbial biomass in control and removal plots throughout 1997 and 1998. At each soil sampling date, the amount of $\mathrm{N}$ in microbial biomass was determined using the chloroform fumigation-extraction method of Brookes et al. (1985). Soil cores $(5 \mathrm{~cm}$ in diameter) were collected to a depth of $10 \mathrm{~cm}$, placed on ice, and transported to the laboratory and processed within $2 \mathrm{~h}$ of collection. Each core was passed through a 2-mm sieve to remove roots and coarse fragments, then two 20 -g subsamples were taken from the homogenized soil. One subsample was fumigated for $24 \mathrm{~h}$ with ethanol-free chloroform $\left(\mathrm{CH}_{3} \mathrm{Cl}\right)$ in a vacuum desiccator and then extracted with $40 \mathrm{ml} 0.5 \mathrm{M} \mathrm{K}_{2} \mathrm{SO}_{4}$, while the other was extracted directly (without chloroform fumigation). Both extracts were analyzed for total $\mathrm{N}$ after Kjehldahl digestion, using a FS 3000 Flow-Injection Analyzer (OI Analytical, College Station, Tex., USA). Microbial biomass $\mathrm{N}$ was determined as the difference in total $\mathrm{N}$ between fumigated and unfumigated samples, divided by a correction factor of 0.54 (Brookes et al. 1985). Amounts of microbial biomass $\mathrm{N}$ ( $\mu \mathrm{g} \mathrm{N} \mathrm{g} \mathrm{g}^{-1}$ soil) were scaled to an areal basis $\left(\mathrm{g} \mathrm{N} \mathrm{m}^{-2}\right)$ using a bulk density of $1.0 \mathrm{Mg} \mathrm{m}^{-3}$ (Holmes and Zak 1994), after which values from the two replicate samples per plot were averaged to generate plot means for statistical analysis.

\section{Effects of spring ephemeral litter on $\mathrm{N}$ mineralization}

\section{Field experiments}

Changes in net $\mathrm{N}$ mineralization in control and removal plots were measured throughout 1997 and 1998. In 1997, net N mineralization was measured using the buried-bag technique (Eno 1960). A pair of soil cores $(5 \mathrm{~cm}$ in diameter) was collected to a depth of $10 \mathrm{~cm}$, including Oi and Oe horizons. One core (the same core used for microbial biomass determination as described above) was placed on ice, transported to the field laboratory, and processed within $2 \mathrm{~h}$ of collection. The other core was sealed, intact, inside a polyethylene bag and placed back in its original position, then allowed to incubate in situ until the next sampling date. Cores were passed through a 2-mm sieve to remove roots and coarse fragments, then a 10-g subsample was extracted with $40 \mathrm{ml} 2 \mathrm{M} \mathrm{KCl}$. The dry weight of this subsample was estimated using the ratio of field-moist weight to oven-dry weight $\left(105^{\circ} \mathrm{C}\right)$ of an additional 10 -g subsample from the same core. Ammonium and $\mathrm{NO}_{3}{ }^{-}$concentrations in soil extracts were determined using the Alpkem
Rapid Flow Analyzer. Net $\mathrm{N}$ mineralization rate was calculated as the amount of $\mathrm{NH}_{4}{ }^{-}-\mathrm{N}$ plus $\mathrm{NO}_{3}{ }^{-} \mathrm{N}$ in incubated cores minus the amount of $\mathrm{NH}_{4}{ }^{+}-\mathrm{N}$ plus $\mathrm{NO}_{3}{ }^{-}-\mathrm{N}$ in initial cores, divided by the number of days of incubation.

Because the buried-bag technique excludes inputs of aboveground litter during the incubation, I switched to a modification of the intact-core, ion-exchange resin method of DiStefano and Gholz (1986) to measure net N mineralization in 1998. In this case, a portion of the forest floor was moved aside and pairs of cores were taken to a depth of $10 \mathrm{~cm}$ from the surface of the mineral soil. The incubated core was left intact in a PVC tube and capped at the bottom with mixed-bed ion exchange resin beads enclosed in nylon stockings. This core was then placed back in the ground with the top open and flush with the soil surface, and then covered with the forest floor. At the end of the incubation period, the soil was processed as described above, while the resin beads were airdried, and then extracted with $100 \mathrm{ml} 2 \mathrm{M} \mathrm{KCl}$ (Hart and Binkley 1984). Net $\mathrm{N}$ mineralization was determined as the difference in $\mathrm{NH}_{4}{ }^{-}-\mathrm{N}+\mathrm{NO}_{3}{ }^{-}-\mathrm{N}$ between incubated and initial soils, plus the amount of $\mathrm{NH}_{4}{ }^{-} \mathrm{N}+\mathrm{NO}_{3}{ }^{-}-\mathrm{N}$ trapped by the resin bag. For both years, rates of $\mathrm{N}$ mineralization from the two replicate samples per plot were averaged to generate plot means, which were used for all statistical analyses.

\section{Laboratory incubation}

In order to better explore the effects of spring ephemeral litter on rates of summertime $\mathrm{N}$ mineralization, I conducted a laboratory incubation experiment throughout the summer of 1998. Because senescent spring ephemeral leaves fall on top of the much larger layer of tree leaf litter, I suspected that $\mathrm{N}$ dynamics associated with the decomposition of the forest floor would overwhelm any effects due to spring ephemeral litter. In addition, a laboratory experiment under uniform conditions would eliminate spatial variation in soil properties that could obscure the detection of the vernal dam effect in the field. To examine these propositions, I incubated soil microcosms with and without forest floor and spring ephemeral litter. On 15 May 1998, I collected one forest floor sample (including senesced spring ephemeral leaves), and five soil cores $(5 \mathrm{~cm}$ diameter by $10 \mathrm{~cm}$ deep), from ten random locations throughout the stand. I used a $930-\mathrm{cm}^{2}$ sampling frame to determine forest floor and spring ephemeral litter mass per unit area. The litter samples were sorted into litter from trees (hereafter referred to as forest floor) and litter from spring ephemerals (hereafter referred to as SE litter). Both components were oven dried at $70^{\circ} \mathrm{C}$, and weighed to determine their mass. Once weighed, all of the forest floor and all of the SE litter samples were composited separately, broken into small $(1-2 \mathrm{~cm}$ diameter) fragments, and thoroughly mixed.

All of the soil cores were passed through a $2-\mathrm{mm}$ sieve, thoroughly homogenized, and distributed evenly into 28 PVC tubes ( $5 \mathrm{~cm}$ diameter by $10 \mathrm{~cm}$ deep) that were sealed at the bottom with nylon mesh (1.5 mm openings). Each PVC tube was filled with soil to a depth of $5 \mathrm{~cm}$. Five replicate subsamples of the composited soil were used to determine initial dry weights and initial $\mathrm{NH}_{4}{ }^{+}+\mathrm{NO}_{3}{ }^{-}$concentrations. Each sample was then randomly assigned to one of four treatments: control, SE litter addition, forest floor addition, and forest floor+SE litter addition. Based on my field collections, forest floor mass was $401 \pm 33.1 \mathrm{~g} \mathrm{~m}^{-2}$, whereas spring-ephemeral litter mass was $5.4 \pm 1.99 \mathrm{~g} \mathrm{~m}^{-2}$. In all treatments receiving forest floor additions, I added enough of the composited forest floor material to the top of the soil column to match field mass $(0.787 \mathrm{~g}$ per core). Because of the patchy distribution of spring ephemeral litter in the field, I added SE litter to those treatments at three times the field mass $(0.032 \mathrm{~g}$ per core $)$. I reasoned that this amount would be representative of areas in the native forest with the highest density of spring ephemerals, and thus the most likely to exhibit a vernal-dam effect. In the case of the forest floor+SE litter treatment, I added forest floor material to the soil surface first, and then placed the SE litter on top of that.

All of the microcosms were incubated at $18^{\circ} \mathrm{C}$ for the next 5 months. Throughout the incubation, at 7- to 14-day intervals, 
each core was watered with $50 \mathrm{ml}$ of a solution designed to simulate rainwater chemistry typical of northern Lower Michigan (1.88 $\mathrm{mg} \mathrm{l}^{-1} \mathrm{NO}_{3}^{-}, 0.5 \mathrm{mg} \mathrm{l}^{-1} \mathrm{NH}_{4}^{+}, 0.1 \mathrm{mg} \mathrm{l}^{-1} \mathrm{Mg}^{2+}, 0.27 \mathrm{mg} \mathrm{l}^{-1}$ $\mathrm{Na}^{+}, 0.41 \mathrm{mg} \mathrm{l}^{-1} \mathrm{Ca}^{2+}, 0.04 \mathrm{mg} \mathrm{l}^{-1} \mathrm{~K}^{+}$, and $0.23 \mathrm{mg} \mathrm{l}^{-1} \mathrm{SO}_{4}{ }^{2-}, \mathrm{pH}$ 5.4; MacDonald et al. 1986). At each watering, the leachate from every tube was collected in specimen cups, weighed to determine volume, and then analyzed for $\mathrm{NH}_{4}{ }^{+}$and $\mathrm{NO}_{3}{ }^{-}$concentration as described above. At the end of the incubation, on 5 October 1998 , the entire contents of each tube were extracted in $250 \mathrm{ml}$ of $2 \mathrm{M}$ $\mathrm{KCl}$, and analyzed for $\mathrm{NH}_{4}{ }^{+}$and $\mathrm{NO}_{3}{ }^{-}$. Rates of mineral $\mathrm{N}$ release in leachate through the course of the experiment were calculated as the amount of $\mathrm{NH}_{4}{ }^{+}-\mathrm{N}+\mathrm{NO}_{3}{ }^{-}-\mathrm{N}$ in the leachate minus the amount of $\mathrm{NH}_{4}{ }^{+}-\mathrm{N}+\mathrm{NO}_{3}{ }^{-}-\mathrm{N}$ in simulated rain, divided by the original dry mass of soil and the number of days since the last watering (ng N g ${ }^{-1}$ day $^{-1}$ ). Total $\mathrm{N}$ mineralization was calculated as the sum of all the mineral $\mathrm{N}$ leached from the tube over the course of the entire incubation and the amount of mineral $\mathrm{N}$ in the final extraction, minus the initial mineral $\mathrm{N}$ present in each tube and all the mineral $\mathrm{N}$ added in simulated rainwater $\left(\mu \mathrm{g} \mathrm{N} \mathrm{g}^{-1}\right)$.

\section{Statistical analyses}

For field experiments, I used repeated-measures analysis of variance (ANOVA), with plot pair as a blocking factor, to analyze differences in soil water $\mathrm{NO}_{3}{ }^{-}$concentrations, microbial biomass $\mathrm{N}$, and rates of net $\mathrm{N}$ mineralization between control and removal plots $(n=5)$. Student's $t$-tests for paired samples were used to compare differences in total $\mathrm{N}$ leaching between control and removal plots. For the laboratory experiment, I used a two-way repeatedmeasures ANOVA, with forest floor and SE litter as main effects, to compare rates of $\mathrm{N}$ release from soil microcosms through the 5 -month incubation $(n=7)$. A standard two-way ANOVA was used to analyze differences in the total amount of $\mathrm{N}$ mineralized in that same experiment. Significance for all statistical analyses was accepted at $\alpha=0.05$.

\section{Results}

\section{Spring ephemeral effects on $\mathrm{N}$ leaching}

A. tricoccum dominated both the biomass and $\mathrm{N}$ dynamics of the spring ephemeral community in this stand (Table 2). Nitrogen uptake from 9 April to 15 May 1997 by the entire spring ephemeral community was $0.446 \mathrm{~g} \mathrm{~N}$ $\mathrm{m}^{-2}$, and A. tricoccum alone accounted for $90 \%$ of this. These rates of uptake were large compared to annual $\mathrm{NO}_{3}{ }^{-}$leaching losses from this ecosystem type of $0.26 \mathrm{~g}$ $\mathrm{N} \mathrm{m}^{-2}$ reported by Holmes and Zak (1999). Despite this, the removal of spring ephemeral vegetation did not have a significant effect on soil water $\mathrm{NO}_{3}{ }^{-}$concentrations in either $1997(P=0.231)$ or 1998 ( $P=0.328$; Fig. 1$)$. In fact, trends toward higher $\mathrm{NO}_{3}{ }^{-}$concentration under removal plots only appeared in the late spring and were greatest during the summer; this pattern occurred in both 1997 and 1998 (Fig. 1). There were no significant differences
Fig. 1A-D Comparison of $\mathrm{NO}_{3}$ - concentrations in soil water at $50 \mathrm{~cm}$, and amount of $\mathrm{NO}_{3}$ - leaching, between control (open symbols or bars) and removal (closed symbols or bars) plots. A, B Data from 1997, C, $\mathbf{D}$ data from 1998. The $a r$ rows represent (1) timing of snowmelt and (2) canopy bud break. Values are treatment means $\pm 1 \mathrm{SE}$
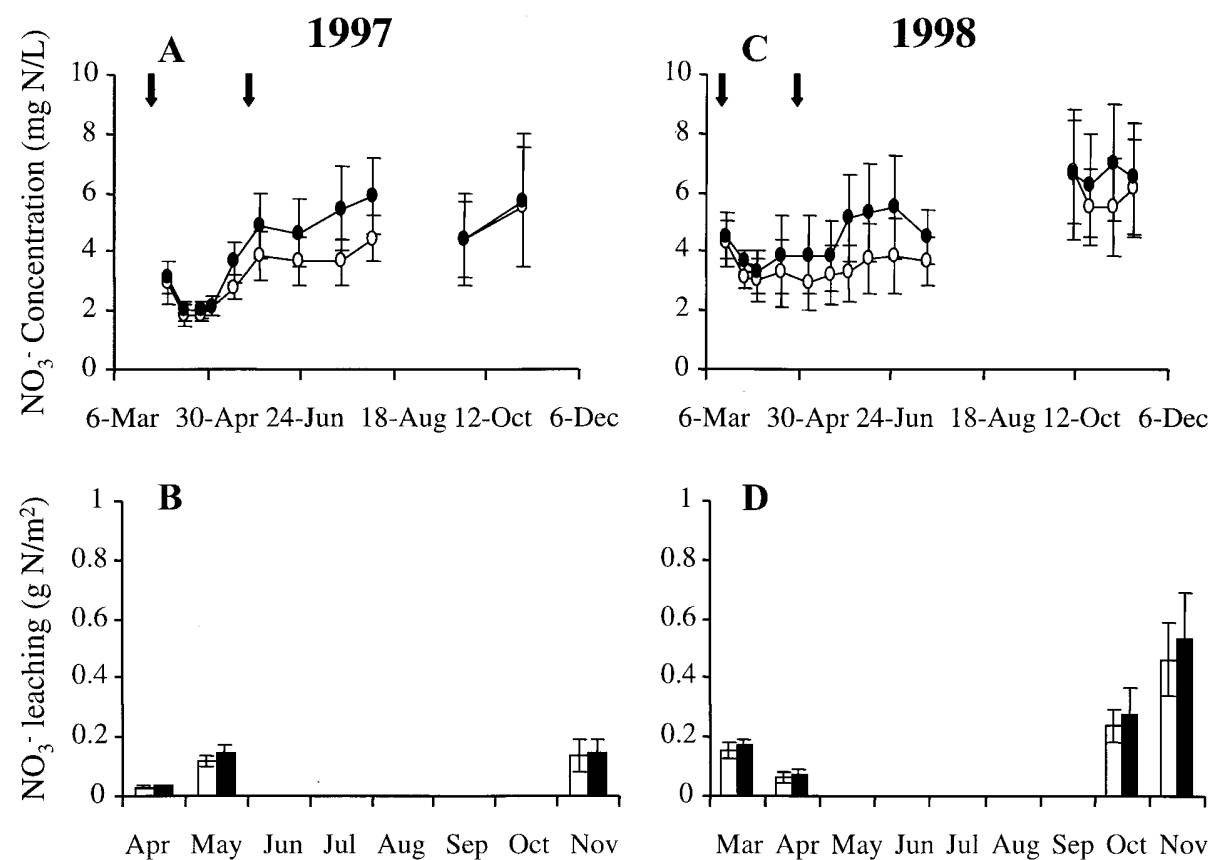

Table 2 Biomass, net $\mathrm{N}$ uptake, and net $\mathrm{N}$ release of spring ephemeral species. Biomass was measured on 15 May 1997. Net uptake of $\mathrm{N}$ was calculated as the difference in $\mathrm{N}$ content between
15 May and 9 April, while net $\mathrm{N}$ release was calculated as the difference between $\mathrm{N}$ content on15 May and 14 June. Values are means \pm 1 SE $(n=10)$

\begin{tabular}{lcllll}
\hline & A. tricoccum & C. virginica & Dicentra spp. & E. americanum & Total \\
\hline Biomass $\left(\mathrm{g} \mathrm{m}^{-2}\right)$ & $45.60 \pm 13.75$ & $2.8 \pm 0.69$ & $4.9 \pm 1.98$ & $2.5 \pm 0.76$ & $55.8 \pm 12.39$ \\
Net uptake $\left(\mathrm{g} \mathrm{N} \mathrm{m}^{-2}\right)$ & $0.406 \pm 0.1204$ & $0.023 \pm 0.0062$ & $0.007 \pm 0.0029$ & $0.010 \pm 0.0028$ & $0.446 \pm 0.1147$ \\
Net release $\left(\mathrm{g} \mathrm{N} \mathrm{m}^{-2}\right)$ & $0.255 \pm 0.0758$ & $0.031 \pm 0.0081$ & $0.016 \pm 0.0073$ & $0.006 \pm 0.0016$ & $0.308 \pm 0.0676$ \\
\hline
\end{tabular}




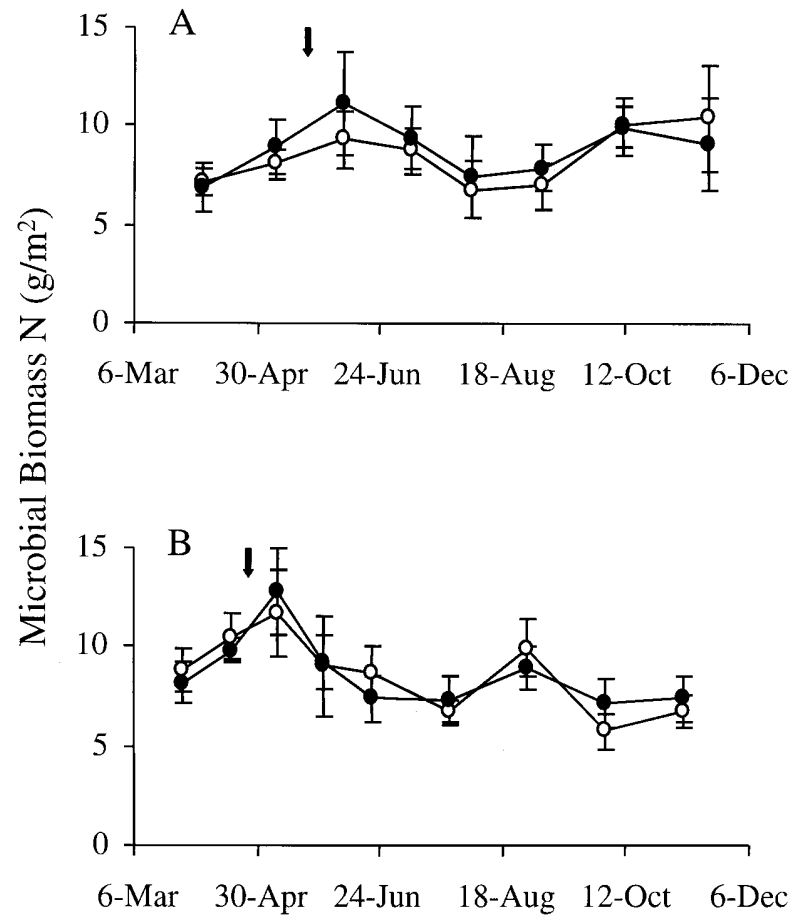

Fig. 2 Seasonal patterns of microbial biomass $\mathrm{N}$ between control (open symbols) and removal (closed symbols) plots for A 1997 and B 1998. The arrow represents the timing of canopy bud break. Values are treatment means $\pm 1 \mathrm{SE}$

in springtime $\mathrm{NO}_{3}{ }^{-}$leaching between control and removal plots in either $1997(P=0.475)$ or $1998(P=0.625)$, neither were there significant differences in total $\mathrm{NO}_{3}{ }^{-}$leaching for either year $(P=0.754$ in 1997 , and $P=0.700$ in 1998).

There were no differences in microbial biomass $\mathrm{N}$ between control and removal plots in either 1997 $(P=0.605)$ or 1998 ( $P=0.723$; Fig. 2). However, there were significant seasonal patterns in microbial biomass $\mathrm{N}$ for both years $(P=0.023$ and $P=0.026)$, whereby the amount of $\mathrm{N}$ in microbial biomass increased from snowmelt to about the time of canopy closure and then decreased into the summer (Fig. 2). Subtracting initial microbial biomass $\mathrm{N}$ from peak microbial biomass $\mathrm{N}$ gives estimates of net $\mathrm{N}$ uptake by soil microbes of 3.2 (1997) and $3.7 \mathrm{~g} \mathrm{~N} \mathrm{~m}^{-2}$ (1998). This method of estimating $\mathrm{N}$ uptake by the microbial community is directly comparable to that used for the spring ephemeral community (described above); by this comparison microbial uptake of $\mathrm{N}$ was nearly 8 times that of spring ephemerals $(P=0.005$; Student's $t$-test). Spring-ephemeral and microbial uptake of $\mathrm{N}$ are contrasted with springtime leaching losses of $\mathrm{NO}_{3}{ }^{-}$in Table 3.

Spring ephemeral effects on $\mathrm{N}$ mineralization

The net release of $\mathrm{N}$ by the spring ephemeral community in early summer averaged $0.308 \mathrm{~g} \mathrm{~N} \mathrm{~m}^{-2}$ and was again dominated by release from A. tricoccum (Table 2). How-
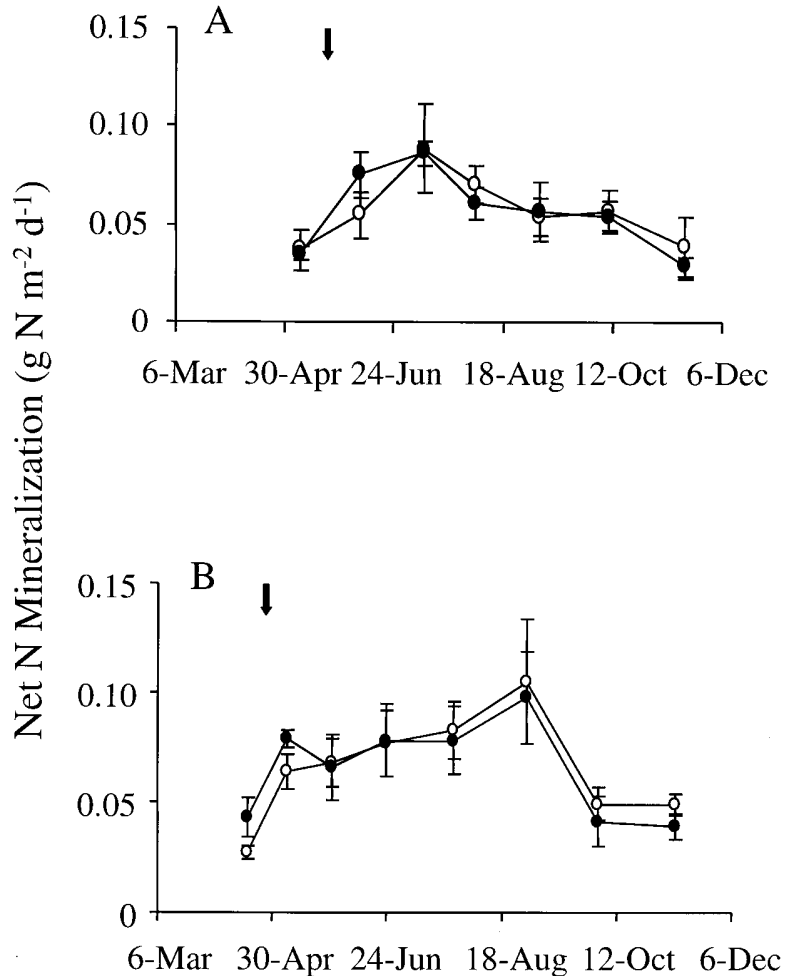

Fig. 3 Seasonal patterns of net $\mathrm{N}$ mineralization between control (open symbols) and removal (closed symbols) plots for A 1997 and B 1998. Each point represents the rate of net $\mathrm{N}$ mineralization over the period between that date and the preceeding one. Initial incubations were begun on 5 April 1997, and 27 March 1998. The arrow represents the timing of canopy bud break. Values are treatment means $\pm 1 \mathrm{SE}$

ever, removal of spring ephemerals had no effect on summertime rates of net $\mathrm{N}$ mineralization in either 1997 $(P=0.721)$ or $1998(P=0.756$; Fig. 3). Net release of $\mathrm{N}$ from soil microorganisms can be estimated in the same manner as release from spring ephemeral biomass by calculating the difference between peak microbial biomass $\mathrm{N}$ in the late spring and the lowest microbial biomass $\mathrm{N}$ in the late summer. By this estimate, 10 times as much $\mathrm{N}$ was released from soil microorganisms after canopy closure as was released from spring ephemerals $(P<0.001$; Student's $t$-test). The release of $\mathrm{N}$ from soil microorganisms and from spring ephemerals is contrasted with the amount of $\mathrm{N}$ mineralized (in field incubations) over the summer months in Table 3.

The presence or absence of spring ephemeral litter had no effect on the total amount of $\mathrm{N}$ mineralized over the course of a five-month laboratory incubation $(P=0.528)$. In contrast, the presence of forest floor material led to dramatic reductions in net $\mathrm{N}$ mineralization $(P<0.001$; Fig. 4A). However, through the course of the incubation, there was a significant three-way interaction between the effects of SE litter, forest floor litter, and time $(P<0.001)$ on the rate of mineral $\mathrm{N}$ release from microcosms. This interaction can be seen in the initial depression of mineral $\mathrm{N}$ release, relative to control, in 
Table 3 Comparison of spring- and summertime $\mathrm{N}$ fluxes in a northern hardwood forest. Springtime values represent $\mathrm{N}$ uptake by spring ephemeral vegetation, $\mathrm{N}$ uptake by microbial biomass, and $\mathrm{N}$ leaching losses for the time period between snowmelt and canopy leaf out. Summertime values represent N release from spring ephemeral vegetation, net $\mathrm{N}$ release from microbial bio- mass, and net $\mathrm{N}$ mineralization from field incubations from the time of canopy leaf out. See text for explanation of calculations. Values are means $\pm 1 \mathrm{SE}\left(\mathrm{g} \mathrm{N} \mathrm{m}^{-2}\right)$. In 1997, ephemeral uptake was significantly less than microbial uptake $(P=0.005$; Student's $t$ test), and ephemeral release was significantly less than microbial release $(P<0.001$; Student's $t$-test $)$

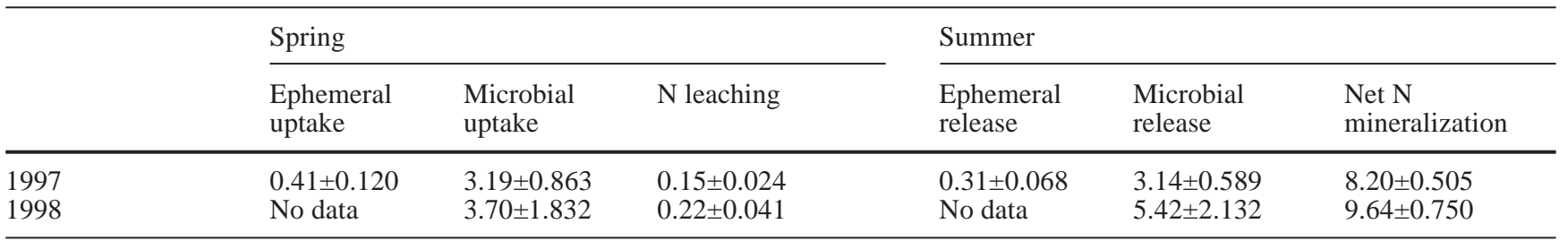
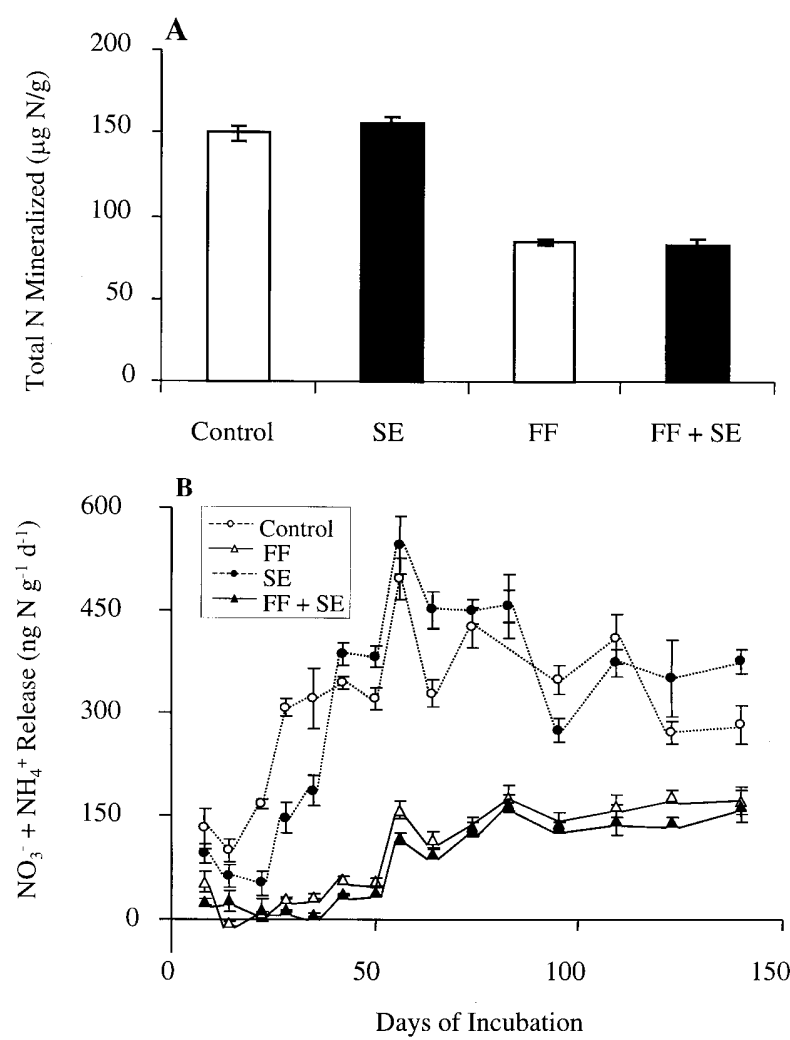

Fig. 4 A Total amount of $\mathrm{N}$ mineralized, and $\mathbf{B}$ patterns of $\mathrm{N}$ release from soil microcosms over a 5-month incubation (control soil alone, $S E$ soil+spring ephemeral litter, $F F$ soil+forest floor, $F F+S E$ soil+forest floor+spring ephemeral litter). Values are treatment means $\pm 1 \mathrm{SE}$

the SE litter alone treatment, and then the subsequent stimulation of $\mathrm{N}$ release after $c a$. 50 days (Fig. 4B). In contrast, mineral $\mathrm{N}$ release was generally greater in forest floor alone than forest floor plus SE litter treatments, although the differences were slight.

\section{Discussion}

Even though $\mathrm{N}$ uptake by spring ephemerals was twice as great as leaching losses of $\mathrm{NO}_{3}{ }^{-}-\mathrm{N}$, I found no evidence to support the contention that $\mathrm{N}$ taken up by spring ephemerals would otherwise be lost from the ecosystem. In fact, applying the same comparison to microbial $\mathrm{N}$ uptake, I found that microbial uptake over this same period was an order of magnitude greater than spring-ephemeral uptake. I also found no evidence, from field or laboratory experiments, that the presence of spring ephemeral litter increased the availability of mineral $\mathrm{N}$ during the summer. While the timing of their growth and development suggests that spring ephemeral herbs could have important effects on ecosystem-level $\mathrm{N}$ cycling, the overwhelming influence of overstory trees obviates any such effects, or at least renders them undetectable by my approach.

The $0.4 \mathrm{~g} \mathrm{~N} \mathrm{~m}^{-2}$ taken up by spring ephemeral vegetation are well within the range of values reported for other eastern deciduous forests: $0.1 \mathrm{~g} \mathrm{~N} \mathrm{~m}^{-2}$ for a northern hardwood forest in New Hampshire (Muller and Bormann 1976), $0.6 \mathrm{~g} \mathrm{~N} \mathrm{~m}^{-2}$ for a beech-maple forest in Indiana (Blank et al. 1980), and $1.1 \mathrm{~g} \mathrm{~N} \mathrm{~m}^{-2}$ for an oakhickory forest in Illinois (Peterson and Rolfe 1982). However, when this uptake was curtailed experimentally, I found no significant increase in $\mathrm{NO}_{3}{ }^{-}$concentrations of soil water. In fact, trends towards higher $\mathrm{NO}_{3}{ }^{-}$concentration under removal plots did not develop until late spring and were greatest in the summer, when there was no potential for hydrologic losses.

Clearly, it is not possible to remove an ecosystem component without creating unintended effects, and it could be argued that results from the lysimeters may be an artifact of such effects. For example, the 1997 pattern of $\mathrm{NO}_{3}{ }^{-}$concentrations in soil water could be explained as the effect of introducing a pulse of relatively labile plant litter - the underground portions of spring ephemerals - to the removal plots. Under this scenario, if decomposition of this material immobilized a similar amount of mineral $\mathrm{N}$ as would otherwise have been taken up by spring ephemerals, equivalent springtime $\mathrm{NO}_{3}^{-}$ concentrations under control and removal plots would result. Then, as decomposition of this material proceeded, $\mathrm{N}$ would be mineralized later in the season, thus explaining the higher summertime $\mathrm{NO}_{3}{ }^{-}$concentrations under removal plots. However, there are two compelling reasons to reject this scenario. The first is the remarkable consistency in patterns of $\mathrm{NO}_{3}{ }^{-}$concentration between 1997 and 1998. Given the apparent effectiveness of the 
removal treatment, if the similar $\mathrm{NO}_{3}{ }^{-}$concentrations between control and removal plots in 1997 were due to decomposition of dead spring ephemerals, we would expect to see greater $\mathrm{NO}_{3}{ }^{-}$concentration under removal plots in the spring of 1998. The second reason is that the seasonal pattern of $\mathrm{NO}_{3}{ }^{-}$- concentrations between control and removal plots is consistent with seasonal patterns of $\mathrm{N}$ uptake by A. tricoccum, the dominant spring ephemeral (Table 2), which has very low rates of springtime $\mathrm{N}$ uptake and accumulates the bulk of its annual $\mathrm{N}$ increment over the summer months (Rothstein 1999). Finally, it is unlikely that an increase in soil $\mathrm{NO}_{3}{ }^{-}$in removal plots was masked by a stimulation of denitrification, because rates of denitrification in this ecosystem are primarily limited by soil water, and are much less responsive to changes in soil $\mathrm{NO}_{3}{ }^{-}$(Merrill and Zak 1992).

While spring ephemeral uptake of $\mathrm{N}$ was large relative to springtime $\mathrm{NO}_{3}{ }^{-}$leaching, net $\mathrm{N}$ uptake by soil microbes was an order of magnitude greater over this same period. These results are consistent with a shortterm, ${ }^{15} \mathrm{~N}$-labelling experiment in which soil microorganisms took up much more $\mathrm{N}$ than did A. tricoccum (Zak et al. 1990). In addition, Groffman et al. (1993) found a similar pattern of increasing microbial biomass $\mathrm{N}$ in the soil of a beech-maple forest in central Lower Michigan. This pattern apparently results from springtime conditions that are conducive to microbial growth: ample substrate due to litter inputs the previous autumn, increasing soil temperature, and abundant soil moisture. Apparently, the strong microbial demand for $\mathrm{N}$ in the spring ensures that rates of $\mathrm{NO}_{3}{ }^{-}$leaching are unaffected by the absence of spring ephemeral uptake. In addition to strong demand for $\mathrm{N}$, microbes are able to compete effectively for both $\mathrm{NH}_{4}{ }^{+}$and $\mathrm{NO}_{3}{ }^{-}$(Zak et al. 1990; Stark and Hart 1997), whereas A. tricoccum takes up mineral $\mathrm{N}$ predominantly as $\mathrm{NH}_{4}{ }^{+}$(Rothstein 1999), a form of $\mathrm{N}$ that is relatively immobile in soil (Nye 1977).

The $0.3 \mathrm{~g} \mathrm{~N} \mathrm{~m}^{-2}$ release of $\mathrm{N}$ from spring ephemeral vegetation observed in this study was similar to the $0.1-0.2 \mathrm{~g} \mathrm{~N} \mathrm{~m}^{-2}$ release from E. americanum reported by Muller and Bormann (1976). However, in my experiment this additional $\mathrm{N}$ did not result in greater rates of summertime $\mathrm{N}$ mineralization in control plots relative to removal plots, most likely because this flux of $\mathrm{N}$ was small relative to $\mathrm{N}$ mineralized from soil organic matter. For example, over the summer months $0.3 \mathrm{~g} \mathrm{~N} \mathrm{~m}^{-2}$ was released from spring ephemerals compared to the 8 to $10 \mathrm{~g} \mathrm{~N} \mathrm{~m}^{-2}$ that was mineralized from soil organic matter. Although spring ephemeral litter decomposes rapidly relative to tree leaves (Muller and Bormann 1976; Peterson and Rolfe 1982), these leaves are deposited directly onto the forest floor, which has been shown to function as a strong sink for $\mathrm{N}$ in other ecosystems (Berg and Staaf 1981; Hart and Firestone 1991).

It could be argued, that if all of the $\mathrm{N}$ in spring ephemeral litter was mineralized rapidly, in the few weeks after canopy closure, an ecologically relevant increase in rates of $\mathrm{N}$ availability would result. Furthermore, because of the spatial variability inherent in the in situ incubations, both in terms of soil heterogeneity and the likelihood of an incubation including spring ephemeral litter, I probably would not be able to detect such an effect in the field. However, the results from the laboratory incubations clearly demonstrate that, even at very high densities, any effect of spring ephemeral litter on $\mathrm{N}$ mineralization is obscured by the overwhelming influence of forest floor and native soil organic matter. In fact, the comparison of $\mathrm{N}$ release between the control and SE litter microcosms shows that decomposition of spring ephemeral litter undergoes at least 1 month of net $\mathrm{N}$ immobilization (Fig. 4B). Results from the microcosm experiment also reinforce the picture outlined above of microbial immobilization as the dominant sink for $\mathrm{N}$ in the spring. The potential for organic substances leached from the forest floor to stimulate microbial immobilization of $\mathrm{N}$ is demonstrated by the marked contrast in the amount of mineral $\mathrm{N}$ leached from microcosms containing forest floor compared to those without.

It is also conceivable that sampling soils from plot edges may have biased results against the detection of a true vernal dam effect on summertime $\mathrm{N}$ availability. Such an edge effect would result if belowground inputs of ephemeral litter from surrounding plants obscured the difference between control and removal plots. This is unlikely for two reasons. First, in A. tricoccum, the dominant ephemeral species, only the top senesces at canopy closure. It maintains its root system throughout the summer and fall (Rothstein 1999). Secondly, as described above, even at very high densities, and under uniform conditions, $\mathrm{N}$ release from ephemeral litter is insignificant compared to mineralization of $\mathrm{N}$ from other pools.

In conclusion, uptake of $\mathrm{N}$ by ephemeral vegetation in the spring was much greater than leaching losses of $\mathrm{NO}_{3}{ }^{-}-\mathrm{N}$ over the same period, but both fluxes were small compared to other fluxes of $\mathrm{N}$ between overstory trees, soil microorganisms, and detrital pools. To put the $0.3-0.5 \mathrm{~g} \mathrm{~N} \mathrm{~m}^{-2}$ net fluxes of $\mathrm{N}$ in and out of the spring ephemeral vegetation into perspective, compare them to the $3.3 \mathrm{~g} \mathrm{~N} \mathrm{~m}^{-2}$ year-1 returned in overstory litterfall and the pool of $213 \mathrm{~g} \mathrm{~N} \mathrm{~m}^{-2}$ in the top $10 \mathrm{~cm}$ of mineral soil reported for this ecosystem type by Zak and Pregitzer (1990). The relative magnitudes of these pools and fluxes are typical for deciduous forests and, along with the results presented herein, demonstrate the overwhelming influence of overstory trees on ecosystem-level $\mathrm{N}$ cycling. Even if their roots are inactive, trees apparently function as an indirect sink for $\mathrm{N}$, mediated by microbial decomposition of tree litter, that is sufficient to limit hydrologic losses of $\mathrm{N}$ during this period. While spring ephemeral herbs are clearly not important in limiting $\mathrm{NO}_{3}{ }^{-}$losses from this ecosystem, results from one site cannot be extrapolated to rule out such an effect in other deciduous forests, particularly ones with different spring ephemeral plant communities. Nor do these results rule out the possibility that spring ephemeral vegetation may limit leaching losses of nutrients other than N. Nevertheless, the results presented herein, in combination with other recent work highlighting the importance of micro- 
bial uptake of N (Kaye and Hart 1997; Stark and Hart 1997), clearly demonstrate that it is unnecessary to invoke an herbaceous "vernal dam" to explain the tightness of $\mathrm{N}$ cycling within deciduous forest ecosystems.

Acknowledgements I thank the USDA Forest Service, North Central Research Station for providing access to the field site and laboratory space. M. Holley, M. Hyde, and M. Tomlinson all provided assistance in the field and laboratory. I gratefully acknowledge D. Zak for his guidance and assistance throughout this project. B. Barnes, L. Nooden, K. Pregitzer, and J. Teeri all provided insightful comments on earlier drafts of this manuscript. This project was supported through a graduate research fellowship from the Matthai Botanical Gardens, University of Michigan, and grants from Sigma $\mathrm{Xi}$ and the School of Natural Resources and Environment, University of Michigan.

\section{References}

Berg B, Staaf H (1981) Leaching, accumulation and release of nitrogen in decomposing forest litter. Ecol Bull 33:163-178

Blank JL, Olson RK, Vitousek PM (1980) Nutrient uptake by a diverse spring ephemeral community. Oecologia 47:96-98

Bormann FH, Likens GE, Melillo JM (1977) Nitrogen budget for an aggrading northern hardwood forest ecosystem. Science 196:981-983

Brookes PC, Landman A, Pruden G, Jenkinson DS (1985) Chloroform fumigation and the release of soil nitrogen: a rapid direct extraction method to measure microbial biomass nitrogen in soil. Soil Biol Biochem 17:837-842

DiStefano JF, Gholz HL (1986) A proposed use of ion exchange resins to measure nitrogen mineralization and nitrification in intact soil cores. Comm Soil Sci Plant Anal 17:989-998

Eickmeier WG, Schussler EF (1993) Responses of the spring ephemeral Claytonia virginica $\mathrm{L}$. to light and nutrient manipulations and implications for the "vernal dam" hypothesis. Bull Torrey Bot Club 120:157-165

Eno CF (1960) Nitrate production in the field by incubating soil in polyethylene bags. Soil Sci Soc Am Proc 24:277-279

Farnsworth E, Nunez J, Farfan J, Careaga SA, Bazzaz FA (1995) Phenology and growth of three temperate forest life forms in response to artificial soil warming. J Ecol 83: 967-977

Gale MR, Grigal DF (1987) Vertical root distributions of northern tree species in relation to successional status. Can J For Res $17: 829-834$

Gleason HA, Cronquist A (1991). Manual of vascular plants of northeastern United States and adjacent Canada. New York Botanical Garden, New York

Groffman PM, Zak DR, Christensen S, Mosier A, Tiedje JM (1993). Early spring nitrogen dynamics in a temperate forest landscape. Ecology 74:1579-1585

Hart SC, Binkley D (1984). Colorimetric interference and recovery of adsorbed ions from ion exchange resins. Comm Soil Sci Plant Anal 15:893-902
Hart SC, Firestone MK (1991) Forest floor-mineral soil interactions in the internal nitrogen cycle of an old-growth forest. Biogeochemistry 12: 103-127

Holmes WE, Zak DR (1994). Soil microbial biomass dynamics and net nitrogen mineralization in northern hardwoods. Soil Sci Soc Am J 58:238-243

Holmes WE, Zak DR (1999) Soil microbial control of nitrogen loss following clear-cut harvest in northern hardwood ecosystems. Ecol Appl 9:202-215

Host GE, Pregitzer KS (1991) Ecological species groups for upland forest ecosystems of northwestern Lower Michigan. For Ecol Manage 43:87-102

Jackson LE, Schimel JP, Firestone MK (1989) Short-term partitioning of ammonium and nitrate between plants and microbes in an annual grassland. Soil Biol Biochem 21:409-415

Jandl R, Kopeszki H, Glatze1 G (1997) Effect of a dense Allium ursinum (L.) ground cover on nutrient dynamics and mesofauna of a Fagus sylvatica (L.) woodland. Plant Soil 189:245255

Kaye JP, Hart SC (1997) Competition for nitrogen between plants and soil microorganisms. Trends Ecol Evol 12:139-143

MacDonald NW, Hart JB, Nguyen PV (1986). Simulated acid rain effects on jack pine seedling establishment and nutrition. Soil Sci Soc Am J 50:219-225

Merrill AG, Zak DR (1992) Factors controlling denitrification rates in upland and swamp forests. Can J For Res 22:15971604

Muller RN, Bormann FH (1976). Role of Erythronium americanum Ker. in energy flow and nutrient dynamics of a northem hardwood forest ecosystem. Science 193:1126-1128

Nye PH (1977) The rate-limiting step in plant nutrient absorption from soil. Soil Sci 123:292-297

Peterson DL, Rolfe GL (1982) Nutrient dynamics of herbaceous vegetation in upland and floodplain forest communities. Am Midl Nat 107:325-339

Rothstein DE (1999) Ecophysiology of three deciduous forest herbs: relationships between physiology, life history and ecosystem-level nitrogen cycling. PhD Dissertation, University of Michigan, Ann Arbor

Stark JM, Hart SC (1997) High rates of nitrification and nitrate turnover in undisturbed coniferous forests. Nature 385:61-64

Tardiff SE, Stanford JA (1998) Grizzly bear digging: effects on subalpine meadow plants in relation to mineral nitrogen availability. Ecology 79:2219-2228

Thornwaite CW, Mather JR (1957) Instructions and tables for computing potential evapotranspiration and the water balance. Climatology 10:185-211

Vitousek PM, Matson PA (1984) Mechanisms of nitrogen retention in forest ecosystems: a field experiment. Science 225:5152

Zak DR, Pregitzer KS (1990) Spatial and temporal variability of nitrogen cycling in northern Lower Michigan. For Sci 36:367380

Zak DR, Groffman PM, Pregitzer KS, Christensen S, Tiedje JM (1990) The vernal dam: plant-microbe competition for nitrogen in northem hardwood forests. Ecology 71:651-656 